\title{
KEBIJAKAN PERENCANAAN DAN PEMBANGUNAN DESA EKOWISATA DAN PARIWISATA DI INDONESIA
}

\author{
Padriadi Wiharjokusumo, Email: knb.ministry76@gmail.com \\ Tourism and Hotel Academy of DarmaAgung
}

\begin{abstract}
Abstrak
Pengembangan desa wisata atau ekowisata membutuhkan perencanaan yang terintegrasi secara matang. Desa menunjukkan peran dan fungsinya sebagai sumber inspirasi pelestarian lingkungan dan budaya. Namun, itu tidak mudah dilakukan. Mengembangkan desa wisata merupakan pekerjaan yang luar biasa, multisektor dan membutuhkan kolaborasi. Perencanaan ekowisata membutuhkan integrasi makro, ekosistem dan tingkat lokal. Perencanaan di tingkat makro memberikan dasar pengelolaan hukum di tingkat ekosistem dan lokal. Perencanaan di tingkat ekosistem menyusun visi lingkungan dan budaya serta mengkoordinasikan pengelolaan regional suatu destinasi. Perencanaan di tingkat lokal mengembangkan pelayanan manajemen yang berkualitas, partisipasi, dan pemberdayaan masyarakat setempat. Pengembangan jasa ekowisata di desa meliputi upaya (i) pengembangan pemberdayaan lokal, (ii) pembangunan infrastruktur untuk memenuhi pelestarian lingkungan, (iii) pembangunan tata kelola untuk mendapatkan pengalaman dan kesejahteraan yang positif, (iv) memadukan promosi pariwisata melalui pengembangan produk dan segmentasi pasar, dan (v) interpretasi dan edukasi untuk menawarkan pendidikan pelestarian budaya dan lingkungan.
\end{abstract}

\section{Kata kunci: Kebijakan, Perencanaan, Pariwisata.}

\section{PENDAHULUAN}

Perkembangan pariwisata memberikan manfaat yang signifikan bagi perekonomian dan daerah. Jasa pariwisata berperan dalam mempercepat proses transformasi ekonomi termasuk di perdesaan. Secara bertahap para petani dapat belajar mengembangkan jasa lingkungan dan sosial di sekitar wilayahnya. Momentum tradisi, budaya, dan eksotisme lingkungan dapat dikemas sebagai layanan wisata desa yang menarik bagi pengunjung dari luar daerah. Konsep budaya dan lingkungan yang bertumpu pada pengembangan pariwisata di desa-desa, akan mensinergikan pembangunan pertanian dan memberikan alternatif kesejahteraan bagi petani. Jasa wisata terbukti menunjukkan kelayakan ekonomi lebih tinggi dari pada bertani (Purnomowati, Nugroho dan Negara, 2012). Konsep ini telah menjadi program unggulan di sejumlah negara, seperti Malaysia (Liu, 2006; Kumar, Gill dan Kunasekaran, 2012) dan Thailand (Chancharoenchai dan Saraithong, 2011).

Peluang pengembangan desa wisata sangat luas. Menurut Parks et al. (2009), masyarakat ekonomi kelas menengah memiliki permintaan yang tinggi untuk perjalanan dan wisata. Sejalan dengan itu, peningkatan infrastruktur khususnya transportasi membangun akses ke berbagai kawasan yang menarik. Mengingat potensi ekonomi daerah pedesaan ini perlu mempersiapkan masyarakat untuk menerima 
kedatangan wisatawan dari luar daerah. Sudah banyak pemerintah daerah yang meningkatkan pengembangan jasa pariwisata pedesaan, dan memberikan manfaat kesejahteraan bagi masyarakat (Nugroho, 2010).

\section{EKOWISATA DAN PARIWISATA DESA}

Ekowisata adalah kegiatan berwisata yang dikemas secara profesional, terampil, dan mengandung unsur pendidikan, sebagai usaha bisnis, dengan memperhatikan warisan budaya, peran serta dan kesejahteraan masyarakat setempat serta upaya pelestarian sumber daya alam dan lingkungan (Nugroho, 2011).

Sebagai usaha ekonomi, efektivitas layanan operasional ekowisata sangat efisien dan ramping. Ciri khasnya adalah jumlah pengunjung yang rendah dalam rombongan, kualitas pelayanan yang tinggi dan nilai tambah yang tinggi. Konsumen ekowisata adalah mereka yang menginginkan liburan dengan sensasi interaksi alam dan budaya. Mereka rela menghabiskan waktu, tenaga dan biaya untuk memuaskan keinginannya. Oleh karena itu pengelola jasa ekowisata perlu menyediakan akomodasi dan juga liburan yang aman dan memuaskan. Disiplin dan standar pelayanan juga merupakan bagian dari upaya perlindungan ekosistem dalam pelayanan ekowisata (Coles, 2006).

Kehidupan desa tidak hanya memberikan pengalaman berbeda dengan kota, tetapi juga dipandang sebagai upaya menciptakan keseimbangan hidup. Pembangunan ekonomi desa berperan dalam penjabaran nilai-nilai kemanusiaan dan lingkungan. Desa dapat menyediakan tempat-tempat yang memberikan kepuasan atau revitalisasi, serta belajar banyak hal khususnya tentang pelestarian lingkungan dan budaya (Nugroho et al., 2016).

Permintaan akan jasa desa wisata, atau berbagai obyek dan kehidupan desa sangat tinggi. Wisatawan sangat penting untuk bepergian menuju desa atau daerah terpencil. Para wisatawan domestik dan mancanegara rela mengeluarkan biaya untuk menempuh jarak jauh. Para wisatawan tinggal di pelosok desa seperti Ngadas atau Ngadisari (Bromo), Candirejo (Magelang), Rajegwesi (negara lain), Wanci (Wakatobi), Komodo (Nusa Tenggara Barat), Taman Nasional Baluran, Raja Ampat (Papua) atau eksotik lainnya. tempat di seluruh Nusantara.

\section{TUJUAN EKOWISATA}

Konsep dan implementasi ekowisata tidak lepas dari pengembangan kawasan lindung. Di Indonesia, kawasan lindung terdiri dari kawasan hutan belantara (WA), kawasan konservasi alam (NCA) dan taman berburu. WA terdiri dari cagar alam yang ketat dan perlindungan hutan belantara; NCA terdiri dari taman nasional, taman hutan raya, dan taman wisata alam. Penetapan kawasan lindung diarahkan oleh Kementerian Kehutanan dan telah mengelola 414 situs yang setara dengan 23,1 juta hektar, terdiri atas 18,4 juta hektar lahan dan 4,7 juta hektar pesisir dan laut (USAID Indonesia, 2004)

Proporsi kawasan lindung yang paling substansial adalah Taman Nasional, yang menyumbang 65 persen dari luas kawasan. Sejauh ini, Kementerian Kehutanan telah menetapkan 53 taman nasional (Tabel 1). Pertimbangan penetapan taman nasional meliputi obyek substantif, kedudukan, ekosistem, jenis tumbuhan dan satwa endemik, dan uraian tugas pelaksanaannya. Oleh karena itu, kelembagaan taman 
nasional dianggap sebagai komponen utama dalam pengelolaan kawasan lindung, serta upaya pelestarian keanekaragaman hayati dalam skala nasional dan internasional (Rothberg, 1999).

Perkembangan ekowisata dalam tataran pengelolaan oleh taman nasional di Indonesia semakin berkembang. Struktur dan fungsi taman nasional menunjukkan kompetensi dalam mendukung pengembangan ekowisata. Taman nasional juga berkontribusi untuk menginisiasi, mendampingi atau memfasilitasi pengembangan ekowisata di desa-desa sekitar kawasan taman nasional.

Kegiatan jasa ekowisata di luar kawasan taman nasional juga berkembang. Daerah tujuan ekowisata biasanya memiliki kearifan, pengalaman, dan nilai budaya yang berbaur dengan lingkungan untuk mendukung kehidupan ekonomi. Kawasan tujuan ekowisata dapat menjadi bagian dari ekosistem pesisir, laut, atau darat; di sekitar kawasan lindung, desa atau kawasan yang memiliki ciri khas nilai warisan untuk generasi penerus.

Pengembangan ekowisata di luar Taman Nasional sangat dikembangkan oleh organisasi masyarakat atau individu. Mereka biasanya memiliki kompetensi dan pengetahuan tentang ekowisata, informasi pasar, modal dan tujuan ekowisata yang potensial. Mereka mendapat respon positif dari masyarakat sekitar yang menerima manfaat sosial, ekonomi dan lingkungan. Alhasil, seluruh pemangku kepentingan bertanggung jawab untuk memastikan keberlanjutan kegiatan ekowisata di sekitarnya.

\section{PERENCANAAN PEMBANGUNAN EKOWISATA}

Dalam RPJMN (2015-2019), pengembangan ekowisata dicapai dalam pengembangan wisata alam, budaya dan kreasi. Kebijakan tersebut dilaksanakan melalui program konservasi keanekaragaman hayati (Kementerian Kehutanan), pengembangan destinasi wisata (Kementerian Pariwisata), serta peningkatan infrastruktur (Kementerian Pekerjaan Sipil). Kementerian Kehutanan mengembangkan kawasan lindung dan taman nasional untuk mendukung pengelolaan jasa lingkungan dan ekowisata. Kementerian Pariwisata setiap tahun memfasilitasi pengembangan 16 destinasi pariwisata domestik; dan 561 desa melalui program PNPM Mandiri. Kementerian Pekerjaan Sipil mengembangkan pelabuhan untuk pengembangan ekowisata bahari dan perairan.

Perencanaan pengembangan ekowisata dilaksanakan dengan memperhatikan aspek ekonomi, sosial dan lingkungan. Weaver (2002) merumuskan kebijakan dalam hierarki sederhana sebagai berikut.

1. Tingkat Makro atau Nasional.

Ruang lingkup perencanaan tingkat makro adalah pembentukan landasan kelembagaan nasional yang memfasilitasi pengembangan ekowisata secara komprehensif. Batas tingkat makro adalah wilayah nasional. Namun, pemerintah juga perlu mengimplementasikan isu-isu lingkungan global. Pemerintah Indonesia (GOI) telah meratifikasi kesepakatan global, misalnya Konvensi Keanekaragaman Hayati, Lahan Basah, atau CITES. Beberapa masalah penting dari kebijakan tingkat makro meliputi:

i. Perkembangan institusi nasional. Kerangka kelembagaan mendorong mekanisme koordinasi dengan lembaga lain di tingkat ekosistem, lokal dan 
internasional. Peraturan perundangundangan dikembangkan untuk memperkuat pengembangan taman nasional, perlindungan suku yang tidak terbantahkan dan situs warisan. Regulasi tersebut memuat substansi batasan, jumlah dan luas areal, lounge area, flora dan fauna yang dilestarikan, pelaksanaan tugas dan tanggung jawab, mekanisme koordinasi dan pemecahan masalah.

ii. Penelitian dan Pengembangan. Penelitian memfasilitasi perencanaan dan pengelolaan di tingkat lokal dan ekosistem. Teori akademis merepresentasikan keterkaitan antara sistem, manfaat dan distribusinya di tingkat lokal serta ekosistem. Hasil penelitian digunakan untuk merumuskan peraturan perundang-undangan, dan mekanisme pengelolaan atau pengembangan taman nasional di Indonesia.

iii. Bantuan teknis dan keuangan. Ini mendorong pertumbuhan ekonomi dan meningkatkan kemakmuran. Anggaran yang dibutuhkan untuk pendidikan dan pelatihan sumber daya manusia, pemasaran, dan pembangunan infrastruktur jalan, jembatan, telekomunikasi, listrik dan air bersih. Pemerintah RI mengambil peran penting dalam rehabilitasi kerusakan lingkungan, pengentasan kemiskinan dan kompensasi kerugian di sekitar kawasan ekowisata.

Indonesia memiliki 17 ribu pulau, 470 suku bangsa, 19 wilayah hukum adat, dan sekitar 300 bahasa, serta keanekaragaman budaya (heritage). Aset tersebut dapat dikemas sebagai pariwisata (Ardiwidjaja, 2006). Memanfaatkan konstelasi geografis akan menghasilkan aktivitas ekonomi potensi pariwisata di seluruh nusantara dan memperkuat wawasan nasional dan geopolitik Indonesia (Pokja Wasantara, 2010).

Peran penting pariwisata dalam aspek ekonomi, sosial dan lingkungan perlu dikembangkan. Dalam aspek ekonomi, sektor pariwisata memberikan kontribusi devisa, kegiatan ekonomi domestik maupun regional. Dalam aspek sosial, pariwisata berperan dalam penyerapan tenaga kerja, apresiasi seni, serta kebanggaan tradisi dan budaya. Itu akan membangun jati diri bangsa. Dalam aspek lingkungan, pariwisata dapat mempromosikan berbagai produk dan jasa wisata serta kehidupan budaya masyarakat setempat. Ekowisata mengembangkan keunikan alam, seperti flora atau fauna di darat, pesisir dan laut. Ini adalah alat yang berguna untuk pelestarian lingkungan alam dan seni dan budaya tradisional.

Pengembangan pariwisata dan sektor pendukungnya memiliki arti penting bagi integrasi nasional. Desa-desa wisata bisa mengikat geografi Kepulauan Indonesia. Pemerintah (GOI) tampaknya hadir dalam memberikan kesejahteraan dan tunjangan sosial kepada penduduk desa. Warga negara yang sejahtera cenderung integratif dan menciptakan relasi yang positif untuk mendukung keberadaan negara dan pemerintahan (Pokja Wasantara, 2010).

2. Tingkat ekosistem

Ruang lingkup perencanaan kawasan ekosistem adalah kawasan ekosistem dan kawasan fungsional lainnya, seperti daerah aliran sungai (catchment area), mangrove, pegunungan, lembah, atau kawasan lain untuk kepentingan konservasi habitat dan budaya (Nugroho dan Dahuri, 2012). Kawasan ekosistem dapat mencakup satu atau lebih komunitas lokal, yang memiliki komponen dan komponen interaksi untuk 
mendukung kesatuan fungsional atau siklus hidup secara teratur. Geografis ekosistem tingkat kebijakan penting berikut ini mencakup:

i. Visi pengelolaan destinasi ekowisata. Suatu ekosistem perlu memiliki visi yang dipahami secara setara oleh semua pemangku kepentingan. Visinya bisa disesuaikan, misalnya konservasi terumbu karang. Penduduk atau operator wisata setempat berkomitmen untuk mengimplementasikan visi tersebut melalui sejumlah kegiatan dalam model pengelolaan yang disepakati kedua belah pihak. Visi tersebut diinformasikan kepada semua pihak yang didukung oleh kerangka peraturan.

ii. Kolaborasi dan Sinergi. Pembangunan daerah didukung oleh sinergi yang menarik dari bidang fungsional lainnya misalnya sektor pertanian, kehutanan atau perikanan. Keterkaitan antar sektor ekonomi akan menghasilkan pertumbuhan ekonomi dan kesejahteraan di daerah-daerah tersebut secara keseluruhan.

iii. Pengelolaan Kawasan Terpadu. Pengembangan kawasan ekowisata yang terintegrasi.

iv. Meliputi jalur trekking, batas wilayah ekosistem atau daerah tangkapan air, atau kawasan khusus untuk habitat dan cagar budaya. Penetapan batas wilayah dimaksudkan untuk mencegah kebocoran arus biaya atau keuntungan yang tidak diperkenankan untuk diterima. Pengelolaan kawasan dirancang dengan cermat berdasarkan kesepakatan para pemangku kepentingan, dengan memperhatikan pelestarian jalur wisata dan melindungi situs-situs yang mengalami kepunahan.
Perencanaan tingkat ekosistem tersebut telah diimplementasikan dalam Peraturan Pemerintah nomor 50 sejak tahun 2010, tentang Rencana Induk Pembangunan Pariwisata Nasional tahun 2010-2025. Kementerian Pariwisata sebagai leading sector telah menetapkan 50 Destinasi Wisata Nasional (NTD). Konsep NTD setara dengan ekosistem atau kawasan fungsional, dimana telah dipromosikan 15 NTD melalui program Destination Management Organization (DMO). DMO tersebut meliputi Sabang, Toba, Kota Tua, Pangandaran, Borobudur, Bromo-Tengger-Semeru, Batur, Rinjani, Flores, Tanjung Puting, Derawan, Toraja, Bunaken, Wakatobi, dan Raja Ampat.

DMO merupakan pembentukan dan pengembangan organisasi pengelolaan destinasi pariwisata berkelanjutan yang berpijak pada proses perencanaan, pengoperasian, dan pemantauan. Program DMO melaksanakannya melalui koordinasi pemerintah pusat dan daerah yang melibatkan masyarakat sekitar, wisatawan, dan pemangku kepentingan lainnya untuk mengembangkan kawasan pariwisata.

3. Tingkat lokal.

Ruang lingkup perencanaan tingkat lokal adalah masyarakat lokal. Pengertian komunitas lokal mencakup orang-orang individu atau kelompok yang memiliki kepentingan dalam subjek ekowisata yang sama. Batasannya adalah aktivitas penduduk lokal dan aktivitas ekonomi. Batasan geografis masyarakat setempat dapat berupa kawasan yang diizinkan oleh pengelola Taman Nasional, wilayah administrasi atau tradisi, desa atau desa adat atau adat istiadat setempat. Beberapa masalah penting untuk kebijakan tingkat lokal meliputi:

i. Partisipasi. Identifikasi partisipasi lokal dan masyarakat merupakan kegiatan 
utama dalam perencanaan daerah. Langkah ini penting untuk menentukan ambang batas populasi dan sejauh mana partisipasi pemangku kepentingan dan implikasinya pada aliran manfaat. Nilainilai lokal perlu diapresiasi sebagai pengalaman substansial dalam pengembangan jasa ekowisata.

ii. Pemberdayaan. Pemberdayaan masyarakat lokal bertujuan untuk mendorong ekonomi lokal menciptakan multiplier effect. Peran dan partisipasi penduduk lokal menjadi sasaran utama dalam pengembangan ekonomi jasa ekowisata. Semakin tinggi perannya, semakin banyak masyarakat lokal yang mendapatkan insentif dalam pelestarian lingkungan.

iii. Mengembangkan kawasan tujuan ekowisata. Batasan aktivitas dan karakteristik usaha, lokasi, serta jalur perjalanan, merupakan bagian integral dari perencanaan manajemen. Spesifikasi ruang atau tempat menjadi motivasi bagi operator dalam penyediaan layanan berdasarkan keunikan ekowisata.

iv. Mengembangkan produk dan layanan pendukung konservasi ekowisata. Masyarakat lokal perlu mengalami banyak pelatihan tentang kewirausahaan, inovasi, dan kepemimpinan. Inovasi tersebut akan mengurangi ketergantungan warga desa terhadap sumber daya alam dan bahan baku. Inovasi pada produk dan jasa menciptakan nilai tambah yang tinggi dan akan memberikan insentif bagi upaya pelestarian lingkungan.

Perencanaan tingkat lokal mengaitkan upaya pemberdayaan, pengembangan, dan pengelolaan ekowisata di desa. Potensi desa wisata bersumber dari kehidupan sosial budaya, lingkungan alam, dan kegiatan ekonomi. Itu bisa menjadi daya tarik wisata di desa. Kehidupan sosial budaya dengan keragaman hunian (rumah dan hunian), kostum etnik (sandang, baju, garmen), kuliner (makanan dan minuman), kesenian, tradisi, nilai atau norma dan dinamika kehidupannya. dapat dipromosikan untuk memberikan nilai tambah dan kemakmuran bagi masyarakat.

Potensi sumber daya alam seperti pegunungan, pantai, danau, laut, lembah, sungai, dapat dimanfaatkan untuk eksplorasi, olah raga atau petualangan. Potensi ekonomi agribisnis (pertanian, kehutanan, perikanan, peternakan, dan kehutanan), industri rumah tangga, atau sektor pendukung lainnya di desa, menjadi nilai tambah pariwisata. Semua potensi ekonomi tersebut dapat berpindah ke dalam kegiatan ekonomi yang didorong oleh faktor-faktor yang kompleks, yaitu permintaan-penawaran, pengaruh internal-eksternal, kreasi-inovasi, kepemimpinan, dan organisasi, serta dinamika kehidupan desa. Klaster ekonomi pariwisata dimulai dari kondisi ini yang disesuaikan dengan situasi desa (Nugroho dan Negara, 2015).

Di tingkat lokal, berbagai kepentingan masyarakat, operator, wisatawan, pejabat pemerintah daerah, atau pejabat taman nasional bertemu untuk saling berinteraksi. Ketidakmampuan untuk berkomunikasi, berkoordinasi atau perbedaan pemahaman tentang ekowisata biasanya ditemukan. Hal tersebut dapat menimbulkan ketidakpastian tentang batasan kewenangan, hak, dan kewajiban. Alhasil, kerap membuat masalah atau konflik. Situasi ini dapat mengancam kelestarian dan keberlanjutan pengelolaan jasa ekowisata. 


\section{PERKEMBANGAN EKOWISATA}

Kegiatan ekowisata perlu terus dikembangkan. Potensi 53 taman nasional belum sepenuhnya direalisasikan, terutama di luar Pulau Jawa yang belum selayaknya dinikmati masyarakat setempat. Pada saat yang sama, faktor lingkungan dan sosial juga relatif rentan terhadap risiko ekonomi pasar berupa eksploitasi sumber daya keanekaragaman hayati.

Posisi kritis dari kebijakan pengembangan ekowisata adalah tingkat implementasi di wilayah lokal. Di tingkat lokal, objek penyediaan jasa ekowisata dan permintaan pengunjung bertemu. Usaha jasa ekowisata menghadapi kendala seperti pada usaha lain. Namun, pengelola jasa ekowisata perlu dikelola lebih serius agar menghasilkan nilai tambah positif bagi kegiatan pelestarian lingkungan dan budaya di desa.

\section{Pengembangan kapasitas lokal}

Masyarakat lokal perlu diberdayakan dengan menyusun kebutuhan mereka dengan kemitraan LSM, pengawas taman nasional dan dukungan pemerintah daerah. Kebutuhan tersebut kemudian diakomodir dalam program konservasi hutan dan pengembangan jasa ekowisata yang berkelanjutan.

Pengalaman Lembaga Swadaya Masyarakat (LSM) ekowisata Indecon menunjukkan bahwa membutuhkan waktu lebih dari dua tahun untuk mendampingi masyarakat Tangkahan, di Taman Nasional Gunung Leuser sehingga dapat berinteraksi secara mandiri dengan pengunjung dan operator tur. Bahkan masyarakat setempat mampu menjadi garda terdepan dalam upaya konservasi, padahal dulu mereka terlibat dalam aktivitas illegal logging.
Saat ini kebutuhan dan kehidupan ekonomi masyarakat di Tangkahan bersumber dari produk dan jasa ekowisata, perkebunan dan kegiatan penunjang lainnya. Kebutuhan kapasitas lokal untuk mendukung pengelolaan pariwisata berkelanjutan meliputi organisasi, kepemimpinan, inovasi produk, dan kewirausahaan (Nugroho dan Negara, 2013). Ini akan memandu pengelolaan konservasi terhadap ancaman seperti penyalahgunaan wewenang, konflik kepentingan, dan distorsi.

\section{Infrastruktur}

Kondisi infrastruktur yang dekat dengan destinasi ekowisata seringkali belum memadai. Mendekati di taman nasional atau desa biasanya belum memuaskan. Terkadang jalan rusak atau longsor pada musim hujan. Ada juga wisatawan yang harus melewati jalur sungai menuju Taman Nasional (terutama di luar Jawa). Angkutan umum untuk bepergian pada malam hari biasanya tidak tersedia. Oleh karena itu, pengunjung harus merencanakan jadwal perjalanannya dengan tepat. Angkutan umum di Taman Nasional Bromo Tengger Semeru bergabung bersama jalur pedagang (Nugroho dan Negara, 2015). Namun secara umum angkutan sepeda motor roda dua lebih leluasa dalam mengantarkan pengunjung kemana saja meski aspek keamanan dan kenyamanan kurang terjamin.

Kendala akses ke taman nasional bukanlah masalah sederhana. Ini juga berkorelasi dengan rendahnya jumlah pengunjung. Semakin banyak pengunjung, tentu mengundang investasi infrastruktur. Tantangan ini membuka peluang bagi masyarakat lokal untuk mendapatkan 
instrumen transportasi. Bisa berupa motor trail, sepeda gunung, kuda, perahu motor atau lainnya, yang disewakan kepada pengunjung dengan memperhatikan aspek kenyamanan, keamanan dan kelestarian lingkungan.

\section{Pemerintah}

Kebijakan pariwisata di Indonesia mengacu pada hubungan antara industri dan pelaksanaan fungsi organisasi. Hubungan industrial ditunjukkan dengan keterkaitan jasa pariwisata dengan sektor lain seperti kehutanan, perkotaan, pendidikan, dan infrastruktur. Sedangkan hubungan fungsi organisasi mengacu pada fungsi perencanaan, tindakan, dan pengendalian (Tabel 2) (Nugroho, 2011).

Pengelolaan industri jasa pariwisata berada langsung di bawah kewenangan Kementerian Kehutanan dan Kementerian Pariwisata. Kedua kementerian tersebut merupakan sektor unggulan yang melaksanakan pengelolaan pariwisata berkelanjutan. Kementerian Dalam Negeri dan Kementerian Desa berperan dalam upaya koordinasi dan pengendalian aliran manfaat bagi masyarakat, masyarakat, dan swasta; melalui kebijakan tata ruang, prosedur investasi dan mata pelajaran teknis lainnya. Koordinasi dan keberpihakan kepada penduduk desa menjadi kunci penting dengan tujuan kenyamanan dan keamanan, menemukan budaya kerja yang produktif dan menikmati kemakmuran. Ketika masyarakat lokal gagal menikmati manfaat tersebut, ancaman konservasi biasanya akan terjadi.

\section{Integrasi promosi}

Upaya promosi dalam mengembangkan ekowisata dapat diarahkan pada dua kategori, yaitu (i) promosi produk dan jasa wisata dan (ii) pengembangan minat wisatawan. Upaya promosi dapat dilakukan dengan mengembangkan harga, posisi, dan produk jasa pariwisata yang potensial. Potensi ini dipandang mewakili sisi penawaran atau karakteristik produk dan jasa ekowisata. Promosi ini merupakan cara standar untuk memperkenalkan sesuatu yang unik atau khas kepada calon traveller secara luas. Meski kurang efektif, promosi ini merupakan salah satu cara untuk membangun dan memelihara citra positif tentang pelestarian lingkungan.

Dalam dunia pariwisata, Bali lebih dikenal dari pada Indonesia. Mengapa? Hal ini terkait dengan informasi tentang Bali dalam aspek budaya dan lingkungan yang lebih luas dan positif daripada Indonesia secara keseluruhan. Informasi terkait Bali ditemukan di banyak tempat di dunia. Angka ini menunjukkan bahwa Bali memiliki positioning yang lebih baik dari Indonesia. Nama Bali menyatu dengan nama kota dan tempat wisata di dunia. Pengembangan jasa ekowisata di suatu daerah perlu mengikuti positioning Bali. Strategi pemasaran ini membutuhkan dukungan pengembangan produk, segmentasi pasar, dan teknologi pemasaran (Nugroho dan Negara, 2015).

\section{Pengembangan produk}

Setiap destinasi pariwisata harus mengedepankan keunggulan produk dan layanannya. Produk-produk tersebut meliputi (Manurung, 2002): (i) pemandangan dan atraksi lingkungan dan budaya, (ii) lanskap manfaat, (iii) akomodasi dan fasilitas layanan pendukung, (iii) peralatan dan perlengkapan, (iv ) pendidikan dan keterampilan, (v) penghargaan dan apresiasi. Produk unggulan harus memenuhi kriteria 
sebagai berikut: unik, asli dan khas yang tidak dapat ditemukan di tempat lain, dengan kemasan yang stylish, aman dan sehat. Wisatawan dilayani dengan nyaman dan berkesan; merasa senang tinggal di desa. Misalnya saja traveller yang senang dengan kuliner khas lokalnya. Makanan atau minuman lokal memberikan sensasi dan daya tarik pariwisata sebagai simbol budaya (Sims, 2009). Masyarakat sekitar perlu mempelajari pengemasan suatu produk sesuai dengan selera wisatawan.

Arah pengembangan produk dan jasa ekowisata ada pada kegiatan interpretasi. Interpretasi adalah pengertian akan suatu objek, sehingga pengunjung mampu bereaksi dan menunjukkan hubungan yang positif antara manusia dengan alam. Menciptakan hubungan tersebut secara positif membutuhkan seorang juru bahasa, yang berfungsi sebagai juru bahasa dan pengenal dari objek yang dikunjungi. Kegiatan interpretasi lahir dari produk kelima yaitu pendidikan dan keterampilan (Nugroho, 2007).

\section{KESIMPULAN DAN SARAN}

Kegiatan jasa ekowisata di desa dapat menjadi solusi permasalahan dalam pembangunan pertanian. Masyarakat lokal yang mampu menjalankan usaha jasa ekowisata akan menikmati kemakmuran. Pada gilirannya, hal ini akan menimbulkan insentif untuk melestarikan sistem produksi pertanian, nilai-nilai dan tradisi budaya serta pelestarian lingkungan.

Perencanaan ekowisata membutuhkan integrasi makro, ekosistem dan tingkat lokal. Perencanaan di tingkat makro memberikan legalitas kepada pengelolaan operasi ekosistem dan tingkat lokal. Perencanaan pada tingkat ekosistem mempertimbangkan visi pelestarian lingkungan dan budaya serta mengkoordinasikan pengelolaan wilayah kawasan tujuan wisata. Perencanaan di tingkat lokal menetapkan layanan manajemen yang berkualitas, membangun partisipasi, dan memberdayakan masyarakat setempat.

Pengembangan jasa ekowisata di desa berkaitan dengan upaya (i) mengembangkan kapasitas lokal untuk meningkatkan pemberdayaan dalam pengelolaan jasa pariwisata, (ii) mengembangkan infrastruktur untuk meningkatkan akses dan menjamin pelestarian lingkungan, (iii) membangun tata kelola dan koordinasi di tingkat nasional hingga lokal yang memastikan keberpihakan kepada masyarakat lokal sehingga mereka memperoleh pengalaman dan kesejahteraan yang positif, (iv) mengintegrasikan promosi dan positioning pariwisata (seperti Bali), melalui pengembangan produk, segmentasi pasar, dan teknologi pemasaran, dan (v) mengembangkan produk yang mengarah pada interpretasi dan pendidikan untuk memberikan pengalaman dan pendidikan konservasi budaya dan lingkungan kepada para wisatawan.

\section{REFERENCES}

Ardiwidjaja, R. 2006. Pariwisata Budaya, Mengapa Tidak Sekarang? www.budpar.go.id/filedata/747_88pariwisatabudaya.pdf [Agustus 2009]

BPS (Badan Pusat Statistik). 2016. Neraca Satelit Pariwisata Nasional (Nesparnas) Tahun2016. BPS Pusat, Jakarta. 
Coles, T. 2006. Suggestions For Developing Tourism in The Wakatobi Islands. Operation Wallacea Trust Project.

Kumar, R., Gill, S. S. dan Kunasekaran, P. 2012. Tourism as a Poverty Eradication Tool for Rural Areas in Selangor, Malaysia. Global Journal of Human Social Science. 12(7): 2126

Liu, A. 2006. Tourism in rural areas: Kedah, Malaysia. Tourism Management 27 (2006): 878-889

Manurung. 2002. Ecotourism in Indonesia. In: Hundloe, $\mathrm{T}$ (ed.). Linking Green Productivity to Ecotourism : Experiences in the Asia-Pacific Region. Asian Productivity Organization (APO), Tokyo, Japan. 98-103

Nugroho, I. 2007. Ekowisata: Sektor Riil Pendukung Pembangunan Berkelanjutan. Majalah Perencanaan Pembangunan-BAPPENAS Jakarta. Edisi 2 tahun ke XII (Januari-Maret): 44-57.

Nugroho, I. 2010. Pengembangan Ekowisata dalam Pembangunan Daerah. Jurnal Pembangunan Daerah. Kementerian Dalam Negeri RI, Jakarta. Edisi 01 tahun 2010. 65-76.

Nugroho, I. 2011. Ekowisata dan Pembangunan Berkelanjutan. Pustaka Pelajar, Yogyakarta. 362p.

Nugroho, I. dan Negara, P. D. 2015. Pengembangan Desa Melalui Ekowisata. Era Adicitra Intermedia, Solo. 281p
Nugroho, I. dan Negara, P. D. 2013. Peran Kepemimpinan dan Inovasi dalam Pengembangan Kewirausahaan Ekowisata Berbasis Penduduk Lokal. Prosiding Seminar Nasional Ekowisata. Diselenggarakan Fak Pertanian Univ Widyagama Malang dan Program Pascasarjana Universitas Brawijaya. Univ Widyagama Malang, 12 Nopember 2013. 